\title{
İslami ve İslam Öncesi İnançlar ve Psikoloji: Türki- ye'de Yerel Sağaltım Yöntemleri Bağlamında Türbe ve Hoca Ziyaretleri
}

\author{
Deniz Canel Çınarbaş \\ Orta Doğu Teknik Üniversitesi
}

\begin{abstract}
Özet
Son yıllarda türbe ziyareti gibi yerel sağaltım yöntemlerinin öneminden ve ruh sağllğına olan faydalarından sıklıkla bahsedilmektedir. Bu tip kültüre ve geleneklere dayalı uygulamaların ve yerel bilgi dağarcığının, tüm psikolojik danışmanlık bilgisini zenginleştireceği ve eski problemlere yeni çözümler bulmada fayda sağlayacağı vurgulanmıştır. Bu doğrultuda, dünyanın çeşitli kültürlerinde ve dinlerinde kullanılan sağaltım yöntemlerini psikolojik faydaları açısından ele alan kitaplar yayımlanmış ve bu yöntemlerin Batılı psikoterapi yöntemleriyle harmanlanmasının önemi üzerinde durulmuştur. Ayrıca, akıl sağlığı çalışanlarının kültürüne ve geleneklerine bağlı kişilerle çalışırken onları bu tip yerel sağaltım uygulamalarına yönlendirmeleri gerekebileceği, bu nedenle de psikoterapistlerin bu kültürel uygulamalar hakkında bilgi sahibi olmaları gerektiği savunulmuştur. Buradan yola çıkarak, bu makalenin amacı Türkiye'deki geleneksel, kültüre ve inançlara dayalı sağaltım yöntemlerini, türbe ve hoca ziyaretleri çerçevesinde özetlemek ve üç türbenin tasviri ve türbe görevlileri ile yapılan görüşmeler bağlamında incelemektir.
\end{abstract}

Anahtar Kelimeler: Yerel sağaltım yöntemleri, türbeler, hoca ziyaretleri, danışmanlık. 


\section{İslami ve İslam Öncesi İnançlar ve Psikoloji: Türkiye'de Yerel Sağaltım Yöntemleri Bağlamında Türbe ve Hoca Ziyaretleri}

Türbe ve hoca ziyareti gibi sağaltım yöntemleri psikolojik, ailevi ya da mali problemleri olanlar tarafindan sıkça başvurulan geleneklerdir. Pepitone'un da belirttiği gibi (1997), dini inançlar ve kültür insanı anlamada önemli unsurlardır ve psikolojinin konuları arasına dâhil edilmelidir. Sosyal yapıyı sosyolojinin konusu, kültürel unsurları da antropolojinin konusu olarak nitelendirip psikoloji alanının dışında tutmaktansa, bu konuları içeren psikoloji çalışmaları insanı daha kapsamlı ve doğru şekilde anlamamıza yardımcı olacaktır. Pepitone (1997) ayrıca inançların psikolojik fonksiyonlarını üç kategori halinde incelemiştir. Birinci kategoride dini inançların temel ihtiyaçları, istekleri ve duyguları karşıladığı, insana umut aşıladığı belirtilmiştir. İkinci kategoride inançların ve bu inançlara bağlı ritüellerin grup bağl11ı̆̆ını arttırdığg belirtilmiştir. Üçüncü kategoride ise açıklanamayan hayat olaylarının din sayesinde açıklanabildiği ve dinin nedensel atıflarda bulunmayı sağladığı belirtilmiştir. Dolayısıyla, dini inançlar insanların birçok ihtiyacını karşılamakta ve psikolojik sorunlarla başa çıkmada da önemli bir yardım kaynağı sunmaktadır. Buradan yola çıkarak, bu makalenin amacı Türkiye'deki geleneksel, kültüre ve inançlara dayalı sağaltım yöntemlerini türbe ve hoca ziyaretleri çerçevesinde ele almak; ve bu türbe ve hoca ziyaretlerini üç farklı türbenin tasviri ve türbe görevlileri ile yapılan görüşmeler bağlamında incelemektir.

Son y1llarda türbe ziyareti gibi yerel sağaltım yöntemlerinin öneminden ve ruh sağlığına olan faydalarından sıklıkla bahsedilmiştir. Örneğin, transkültürel psikiyatri çalışmaları kapsamında, Mısır'da yaygın olan Kuran bazlı sağaltım yöntemleri ele alınmış, bunların psikiyatriyle bağlantıları tartışılmıştır (Coker, 2009). Bu çalışmada, Mısır'da yayımlanan Arapça gazetelerde yer alan Kuran bazlı sağaltım yöntemleri ile ilgili haberler niteliksel yöntemlerle incelenmiş, bu yöntemin modern Misır kültüründeki yeri ele alınmıştır.

Ayrıca, Kirmayer (1999) kültüre dayalı sağaltım yöntemlerinin çalışma mekanizmalarını incelemiş ve dört temel mekanizmadan bahsetmiştir. Bunlar: (a) olumlu beklentilerin etkisi ve sağaltıcının ve yöntemin otoritesi, (b) yeni bilişsel şemaların veya olayların ve deneyimlerin alternatif yorumlarının oluşturulması, (c) ritüellerin ve imgelerin estetik değerlerinin acıya anlam ve bütünlük katması, (d) hastanın ritüellerde aktif rol oynayarak kendi sorumluluğunu üstlenmesi ve inisiyatif almasıdır (Kirmayer, 1999). Bu mekanizmaların türbe ve hoca ziyaretlerinde de etkin oluğu söylenebilir. Örneğin, türbe ziyaretlerinde, ziyaretçiler dualarla ve dileklerle sorunlarına olumlu bir çerçeveden bakabilmekte, bu sorunların çözümü için eyleme geçmektedirler. Yine hoca ziyaretlerinde, hoca nazarla ya da dini başka açıklamalarla sorunlara alternatif açıklamalar getirebilmekte, hastanın bilişsel şemalarını değiştirebilmektedir.

Kuzey Amerika kaynaklı psikoloji çalışmalarında, özellikle de danışmanlık psikolojisi çalışmalarında da bu konudan bahsedilmiştir (Gerstein, Heppner, Ægisdottir, Leung ve Norsworthy, 2009). Bu tip kültüre ve geleneklere dayalı uygulamaların ve yerel bilgi dağarcığının, tüm psikoloji bilgisini zenginleştireceği ve eski problemlere yeni çözümler bulmada fayda sağlayacağı vurgulanmıştır. Bu doğrultuda, dünyanın çeşitli kültürlerinde ve dinlerinde kullanılan sağaltım yöntemlerini psikolojik faydaları açısından ele alan kitaplar yayımlanmış ve bu yöntemlerin Batılı psikoterapi yöntemleriyle harmanlanmasının önemi üzerinde durulmuştur 
(Moodley ve West, 2005). Kültürel değerlerine ve geleneklerine bağlı kişilerle çalışırken bu kişileri doğru kültürel sağaltım uygulamalarına yönlendirme gereğinin ortaya çıkabileceğini öne süren Atkinson, Thompson ve Grant (1993), bunu yapabilmek için psikolog ve psikolojik danışmanların bu tür kültüre özgü uygulamalar hakkında bilgi sahibi olması gerektiğini savunmuştur.

Türkiye'de de yerel sağaltım yöntemleri mevcuttur ve sıklıkla kullanılmaktadır. Bu yöntemlerin İslam öncesi ve İslami geleneklerin bir karışımı olduğu söylenebilir. Türkiye nüfusunun yaklaşık \%97'sinin Müslüman olduğu (Çarkoğlu ve Toprak, 2000) ve bu Müslüman nüfusun \%90'ının Sünni mezhebinden olduğu (Engin-Demir, 2003) belirtilmiştir. Benzer şekilde, dünyanın birçok farklı ülkesinde yaşayan Türkiyeli nüfusun da \%90'1 Müslüman'dır (İnan, 1972). İslam'dan önce Orta Asya'da yaşayan Türk boyları arasında Görktanrı Kültü, Animizm ve Ata Kültü gibi inançlar yaygınken, 10. yüzyılda Türkler İslam inancına geçiş yapmışlardır (Ocak, 2000). Ancak, tüm Türklerin İslam'a geçişi aynı zamanda olmamıştır. Örneğin, günümüzde Anadolu'da yaşayan Türklerin atası sayılan Oğuz Türklerinin İslam'a geçişleri iki yüzyıl sürmüştür. Bu süreçte Türkler bir yandan İslam'a ait yeni inançları benimserken diğer yandan da daha önceki inançlarından bazılarını korumuşlardır (İnan, 1972). Sonuç olarak, İslam öncesi inançlarla İslami inançlar birbirine karışmış ve bunların bütünü günümüz Türkiye'sindeki kültürel ve geleneksel tedavi ve sağaltım yöntemlerinin temelini oluşturmuştur (Canel-Çınarbaş, Korkut-Owen ve Çiftçi, 2009).

Günümüzde İslam öncesi inançların kültüre dayalı sağaltım yöntemleri üzerindeki etkisi sürse de, İslami inançlar daha güçlü bir unsur olarak etkisini göstermektedir. İslami inançlara göre Müslümanlar, ruhsal ve fiziksel hastalıkları engellemek ve iyileştirmek için modern tıbbı ve bilimsel yöntemleri kullanmalı, ellerinden geleni yapmalıdırlar (Diyanet İşleri Başkanlığı, b.t.). Bu yöntemlerden netice alamadıklarında ise hastalığı ve hatta ölümü tevekkülle ve sabırla karşılamayı bilmelilerdir (Rassool, 2000). Müslümanlar hastalığın hayatın bir parçası olduğuna ve Allah tarafından gönderilmiş bir sınav olduğuna inanırlar (Rassool, 2000). Bu inanca göre her şey Allah’tan gelir; hastalığg da çaresini de veren sadece Allah’tır (Diyanet İşleri Başkanlığı, b.t.). Dolayısıyla İslami inanca göre hastalığın dahi bir hikmeti vardır. Hastalığın günahlardan arınmak için bir vesile; fiziksel, duygusal, zihinsel ve ruhani açılardan dengeye ulaşmak için bir araç olduğuna inanılır (Rassool, 2000).

Tüm bu inanışlara paralel olarak, İslami tıp bütüncüldür ve hem bedenin hem de ruhun sağlığına önem verir. Örneğin, Müslümanların kutsal kitabı olan Kur'an-I Kerim'in beden ve ruh üzerinde direkt bir iyileştirici etkisi olduğuna inanılır (El-Kadi, 1993). Dini yetkililer ruhsal ve fiziksel hastalıkları iyileştirmek için Kur'an-I Kerim'den ilgili bölümlerin okunmasını ve dua edilmesini tavsiye ederler (Diyanet İşleri Başkanlığı, b.t.). Buna bağlı olarak da, Türkiye'de insanlar fiziksel ve psikolojik problemlerin çözümü için hem tıp doktorlarından ve psikologlardan, hem de dini yetkililerden ve hocalar gibi geleneksel sağaltıcılardan yardım almayı alışkanlık haline getirmişlerdir (Bolak-Boratav, 2004).

Diğer yandan, Göktanrı Kültü, Animizm ve Atalar Kültü gibi İslam öncesi inançlar, hayatla, hastalıkla ve tedavisiyle ilgili daha farklı bir görüşü ileri sürmüşlerdir (İltar, b.t., Ocak, 2000). İslam öncesi bu inançların aslında bir inançlar bütünü olduğu düşünülmekte ve bu bütüne Türk Şamanizm'i de denmektedir (Kalafat, 1998). Göktanrı inancına göre gögü ve yeri yaratan tek bir tanrı vardır. Bu inançta gök ruhu, yer ruhu gibi iyi, yani ak ruhlar ve ayrıca kötü, yani kara ruhlar vardır. Her türlü iyilik ve kötülük ruhlardan gelir ve bu yüzden insanların bu ruhları memnun etmesi ve öfkelendirmemesi gerekir. Kam adı verilen dini lider ise ruhlarla insanlar arasındaki bağlantıyı kuran kişidir. Bu inanç sistemi bağlamında Türkler, Kam'ın liderliğinde nehir kenarlarında tanrıya tapınma ayinleri düzenlemiş ve tanrıya şükretmek için hayvan kurban 
etmişlerdir (Kalafat,1998).

Hem Göktanrı Kültünde hem de Atalar Kültünde, ataların önemli bir yeri vardır. Ataların ruhlarına y1lın belli zamanlarında hayvanlar kurban edilir ve hediyeler sunulurdu (İltar, b.t.). Bu inanca göre ataların ruhu insanları korur ve kollar, aile ve boy fertleri ise atanın ruhundan bir şey dilemek için armağanlar sunar ve kurban keserlerdi. Günümüzde uygulanan, mezarlıklarda şeker dağıtmak, ölen aile üyesinin sevdiği yemekleri yaparak ölenin ruhuna fakirlere veya komşulara dağıtmak, helva dağıtmak, mezarın başına yemek veya bir testi su bırakmak gibi gelenekler İslam öncesi inançların bir devamı olarak görülmektedir (Çıblak, 2002).

Bir diğer İslam öncesi inanç sistemi olan Animizm'e göre, nehir, su kaynağı, dağ, ağaç gibi cansız varlıkların da ruhu vardır. İnsanlar, bazı tepeleri, dağları ve ağaçları kutsal sayar ve bu kutsal yerlere giderek dua eder ve dilekte bulunurlardı. Orta Asya'dan göç eden Türk kavimleri bu tür inançları Anadolu'ya taşıyarak Orta Asya'da kutsal sayılan dağların adlarını Anadolu'daki dağlara vermişlerdir. Örneğin, Baba Dağ hem Orta Asya'da hem de Anadolu'da bir dağ adıdır (Demir \& Çomak, 2009).

Animizmin ve Türk Şamanizm'inin izleri günümüzde İslami inançlarla ve geleneklerle iç içe geçmiştir (İnan, 1952). Örneğin, tıpkı Orta Asya'da çocuk sahibi olmayı dilemek için ağaçlara bez bağlayan ataları gibi, Türk Müslümanlar da ağaçlara bez ve ip bağlayarak dua eder ve dileklerde bulunurlar. Bu gelenek, aslen ağaçların da ruhu olduğuna ve onlara hediyeler sunarak ruhunu memnun etme yoluyla dileklerin geçekleşeceğine olan inançtan kaynaklanmaktadır. Türklerde İslam öncesi inançlarla İslam inancının harmanlanmasına bir başka örneği de, su kaynağının çevresinde bulunan çalılara bez bağlama geleneğidir. Örneğin, Ankara yakınlarında bulunan bir su kaynağının etrafında insanlar çalılara bez bağlayarak Kuran' dan ayetler okur, hastalıkları, ailevi veya psikolojik problemleri için çare ararlar. İnan (1952), kutsal sayılan su kaynaklarının veya ağaçların etrafında İslami ve dini liderlere ait türbelerin de bulunabildiğini, fakat buralarda dilek dileme geleneğinin, ağaçların, su kaynaklarının ve tepelerin de ruhu olduğu esasına dayanan eski Şaman inancının İslam'la birleşmesi olarak yorumlanması gerektiğini belirtmiştir.

Öte yandan, İslam âlimleri ağaçlara bez bağlamak, nazar boncuğu takmak veya Allah haricinde kişilerin ruhlarına dua etmek gibi adetlerin İslam'a aykırı olduğunu ve Müslümanlarca uygulanmaması gerektiğini vurgulamaktadırlar (Diyanet İşleri Başkanlığı, b.t.). Türk Müslümanlar ise bu adetleri İslam'la bağdaştırabilmekte ve günlük hayatlarında bir nevi sağaltım yöntemi olarak uygulamaya devam etmektedir.

\section{Türbe Ziyaretleri}

Türkiye'de yüzlerce türbe bulunmaktadır. Bu türbeler arasında, Osmanlı Padişahları, İslam âlimleri, Mevlevi dervişler, kutsal savaşlarda şehit düşenler, efsanevi kişilikler ya da bilinmeyen kişiler için inşa edilmiş olanlar bulunmaktadır (Kalafat, 1998; Tanyu, 1967). Bu türbelerin bazıları Diyanet İşleri Başkanlığı'na veya müftülüklere bağlıyken, diğerleri derneklerin veya mahalli birliklerin himayesi altındadır. Türbelerden bazıları külliye mahiyetindeki kapsamlı yapıların bünyesinde inşa edilmişken, diğerleri tek bir yapıdan ya da mezardan oluşmaktadır. Örneğin, bazı türbelerin etrafında cami, abdesthane, avlu, adaklık ve Diyanet İşleri'ne bağlı ofisler ya da kitap satış mağazaları vardır. Ayrıca, birçok türbenin etrafında özel işletmelere ait dükkânlar ve lokantalar da bulunabilmektedir. Ziyaretçiler buralardan, tespih, başörtüsü gibi dini nitelikte eşyalar alabilmekte, yiyecek içecek satın alıp, buralarda vakit geçirebilmektedir (Canel-Çınarbaş, Çiftçi, \& Bulgan, 2013). Böylece türbeler, ziyaretçilerin günlerini sosyalleşerek, yemek yiyerek ve alış veriş yaparak geçirebilecekleri yerler haline gelebilmektedir. 
Türbe ziyareti Türkiye'de oldukça yaygın bir gelenektir. Dini davranışlarla ilgili kapsamlı bir araştırmada, Çarkoğlu ve Toprak (2000) katılımcılardan \%52,7'sinin en az bir kez türbe ziyaretinde bulunduğunu tespit etmiştir. Türbe ziyaretleri özellikle Cuma günleri ve dini bayramlarda yapılsa da, yılın her gününde türbelerde ziyaretçi görmek mümkündür. Bazı mahalleler ya da belediyeler türbelere ziyaret için günlük turlar düzenlemekte, birçok türbenin ziyaret edildiği bu turlarda ziyaretçilerin ulaşımını sağlamak için otobüsler kiralamaktadırlar. Ziyaretçiler türbelere genellikle komşuları, arkadaşları ya da akrabalarıyla gelmektedirler. Ziyaretçiler arasında, erkeklere nazaran kadınların daha fazla olduğunu gözlemlemek mümkündür. Bazı ziyaretçiler sırf türbeyi ziyaret edebilmek için şehir dışından gelirken, bazıları da şehre başka bir nedenden gelmişken şehir turu kapsamında türbeleri de ziyaret etmektedir (Canel-Çınarbaş ve ark., 2013).

Türbe ziyaretleri sırasında daha mütevazı ve kapalı kıyafetler tercih edilmektedir. Kadınların çoğu uzun kollu ve uzun etekli giysiler giyip başını örtmekte, bazıları da kısa kollu kıyafetler veya pantolon giyip türbe dışında başını açtığı halde türbeye girerken başını örtmektedir. Ziyaretçiler genellikle abdest alıp, eğer türbenin çevresinde cami varsa ve namaz vaktiyse namaz kılar, mezarı ziyaret ederek Kuran'dan ayetler okuyup dualar ederler. Türbelerin çevresinde ellerinde kitapçıklar, Kuran'dan Arapça ayetler okuyan ya da Türkçe dualar eden ziyaretçiler görmek mümkündür. Eğer mümkünse ve vakit varsa, grupça gelmiş ziyaretçiler genellikle türbenin etrafında oturarak yanlarında getirdikleri yiyecek içecekleri paylaşıp sohbet ederler. $\mathrm{Bu}$ ortamlarda paylaşımın, örneğin insanların birbirlerine, hatta yabancılara yiyecek ikram etmesinin önem kazandığ 1 gözlemlenebilir (Canel-Çınarbaş ve ark., 2013).

Ne var ki, tüm bu aktivitelerin yanında türbe ziyaretlerinin asıl amacı dilek dilemek veya daha önceden kabul edilmiş bir dileğin adağını yerine getirmektir. Yaygın olarak karşılaşılan dileklere örnek olarak sağlık, hastalıklara çare, psikolojik veya ailevi problemlere çözüm, askere giden bir erkek evladın sağ salim dönmesi, çocuğu olmayan kadınların çocuk, hatta genelde erkek çocuk sahibi olması, uygun bir eş ya da iş bulma verilebilir. Ziyaretçiler bir dilekte bulunduktan sonra, kurban kesmek, fakirlere sadaka vermek ya da şeker dağıtmak gibi adaklar adayabilirler. Bu insanlar dilekleri gerçekleştiği takdirde türbeyi yeniden ziyarete gelir ve adaklarını yerine getirirler. Dolayısıyla, türbelerin etrafında adaklarını yerine getirmek için lokum veya kesme şeker dağıtan ziyaretçiler görmek mümkündür. Hatta bazı ziyaretçiler kestikleri kurbanın etini dağıtır ya da türbeye bağışta bulunabilirler (Canel-Çınarbaş ve ark., 2013).

Türbelerde dilek dilemeyle ilgili çeşitli görüşler bulunmaktadır. Bazı ziyaretçiler sadece Allah'a dua edilmesi ve ne dilenecekse Allah’tan dilenmesi gerektiğini, diğer her türlü davranışın günah sayılacağını belirtirken, bazıları da türbede yatan kişinin ulu ve Allah katında makbul bir kişi olduğunu, bu nedenle o kişinin "yüzü suyu hürmetine" Allah'tan dilemenin daha çok kabul görebileceğini belirtmektedir. Diğer bazı ziyaretçiler ise, insanın evinde otururken de Allah'tan dilek dileyerek dua edebileceğini, fakat türbelerin kutsal mekânlar olmasından dolayı ziyaretçilerin hayatları ve problemleri hakkında daha etraflıca düşünme firsatı bulabileceklerini, problemlerini çözme yolundaki aşamaları daha rahat planlayarak hayatlarını gözden geçirebileceklerini, daha gönülden dua edeceklerini, bu nedenle de türbede dilenen dileklerin evde dilenenlerden daha etkili olabileceğini belirtmiştir (Canel-Çınarbaş ve ark., 2013).

Türbelerde, özellikle Müftülüklere bağlı olanlarda, türbedeki davranışları ve ibadetleri düzenleme amaçlı yazılar ve levhalar bulunmaktadır. Bu levhalar, türbede yatan kişiye dua ederek dilek dilenmeyeceğini, türbenin etrafına bez ya da ip bağlanmayacağını, tavuk gibi iki ayaklı hayvanların kurban için uygun olmadığını, bu tip davranışların İslam'a aykırı olduğunu, sadece Allah'a dua ederek ondan dilek dilemenin uygun olduğunu belirten uyarılar içermektedir. $\mathrm{Bu}$ uyarıların amacı, İslam öncesi inançların etkisiyle ortaya çıkan bazı gelenekleri yerine getirmek isteyen ziyaretçileri İslami uygulamalara yönlendirmektir. Bu nedenle, ziyaretçiler İslam öncesi 
pratikleri uyguladıkları veya uygulamak istedikleri halde bunları beyan etmekten çekinebilmektedirler (Canel-Çınarbaş ve ark., 2013).

Ziyaretçiler türbe ortamında huzur bulduklarını, sıkıntılarından kurtulduklarını ve dilek dileyerek rahatladıklarını belirtmişlerdir (Köse \& Ayten, 2010). Türbe ziyaretlerinin ruhsal etkileri ile ilgili çeşitli açıklamalar mevcuttur. Örneğin, ziyaretçiler türbeyi ziyaret ederek isteklerinin gerçekleşmesi için kendilerine biraz daha süre tanırlar, hedeflerini canlı tutarlar, ellerinden geleni yaptıklarını düşünerek kendilerini motive ederler. Türbe ziyareti ayrıca, ziyaretçilere ümit aşılar, kendilerini ifade etmeleri ve dertlerin anlatmaları için vesile olur, hatta problemlerini kutsal alana taşıma hissiyle ziyaretçileri rahatlatır. Ziyaretçiler, manevi bir ortamda olma hissiyle huzur duyarlar, katı dini kuralların olmadığı bu mekânda diğer ziyaretçilerin dertlerini paylaşarak yalnızlık hissinden kurtulur ve rahatlarlar (Köse \& Ayten, 2010). Benzer problemler yaşayan başkalarının da olduğunu fark etmek kişiye yalnız olmadığını hatırlatır. Yalom'a göre (Yalom \& Leszcz, 2005), grup terapisini etkin kılan mekanizmalardan biri de evrensellik faktörüdür. Buna göre grup terapisine katılanlar, kendileri gibi problem yaşayan diğer grup üyeleriyle tanışırlar ve böylece yalnız olmadıklarını fark ederler. Böylece iyileşmeye bir adım daha yaklaşırlar. Aynı terapötik faktörün türbe ziyaretleri için de geçerli olduğunu söylemek mümkündür.

\section{Hoca Ziyaretleri}

Hoca kelimesi Türkçede birçok farklı anlamı olan bir kelimedir ve bu anlamlardan biri de "İslami din görevlisi"dir. Diyanet İşleri Başkanlığı tarafından görevlendirilen hocalar genelde camilerde görev alır, namazlarda cemaati yönlendirir, özel günlerde veya Cuma günleri dini konularda bilgilendirici konuşmalar yapar ve bu görevleri yerine getirme karşıllı̆ında Diyanet İşleri Başkanlığg'ndan maaş alırlar (Stirling, 1965). Bu anlamının yanı sıra, "hoca" kelimesi, Diyanet İşleri Başkanlığınca resmi olarak görevlendirilmemiş fakat bazı kişilerce konusunda yetkin olduğu kabul edilen ve dini açıdan sağaltım gücü olduğuna inanılan kişiler için kullanılır. Uzmanlık alanlarına bağlı olarak bu gayri resmi hocalar hastalıkları iyileştirebilir, ailevi problemleri çözmek için büyü yapabilir, muskalar hazırlayabilir, dualar okuyup üfleyebilir ve cin çıkarmak için bazı yöntemler uygulayabilir. Bu tip hizmetleri karşılığında hoca, gelen kişiden ücret talep edebilir (Bellér-Hann \& Hann, 2001).

Özdemir ve Frank (2000) bu ikinci tip hocalara Müslüman Şaman ismini vermiştir. Özdemir ve Frank (2000) şamanı, "inananları tarafından metafiziksel güçlere sahip, fizik ötesi âlemle iletişim içinde olan, mistik bilgilere sahip, ruhani güçleri uyandırarak kişilere veya olaylara şekil verebilen bir kişiı” olarak tanımlamış (Özdemir ve Frank, s. 61), şaman Müslümansa ve yöntemlerini İslami bir formatta uyguluyorsa, bu kişiye Müslüman şaman denilebileceği belirtilmiştir.

Başka yazarlar da hocalarla şamanlar arasındaki benzerliklerin altını çizerek Müslüman şaman tanımına destekleyen incelemelerde bulunmuşlardır. Örneğin Ocak (2000), Türklerin Anadolu'ya yeni göç ettikleri dönemlerde Anadolu'da Müslüman hocaların ve sağaltıcıların bulunduğunu ve bu kişilerin büyü ve tedavi ritüelleri gerçekleştirdiklerini belirtmiştir. Ocak ayrıca bu hocaların görevlerinin ve yöntemlerinin şamanlarınkiyle benzeştiğinden bahsetmiştir. İnan (1952) ise, özellikle Alevi ve Bektaşi inancındaki dini liderlerin Türklerdeki şaman rolünü üstlendiklerini belirtmiştir.

Bir çalışmalarında Bellér-Hann ve Hann (2001) Müslüman şamanların faaliyetlerine çeşitli örnekler vermişlerdir. Birinci örnekte, hamileliğiyle ilgili sağlık problemleri yaşayan bir anne adayı, kadın olan bir Müslüman şamana başvurmuş. Şaman anne adayına tedavi süresince yedi ayrı kaynaktan su alıp her gün bu sudan içmesini söylemiş. Müslüman şaman ayrıca bir muska yazmış ve kadını okuyup üflemiş. Bir diğer örnekte, bir kişi cinlerle ilgili kâbus görme şikâyetiyle 
Müslüman şamana başvurmuş. Cinler bu kişinin rüyalarına ya bir yılan ya da vücudu olmayan kocaman bir kafa olarak giriyormuş. Müslüman şaman bir tas suyu okuyup üflemiş ve kendisine başvuran kişiden bu tasa bakmasını istemiş. Kişi rüyalarına giren şekli bu tastaki suda görünce tedavi olmuş (Bellér-Hann ve Hann, 2001).

Türkiye'de birçok kişi Müslüman şamanlardan yardım almaktadır. Ünal ve arkadaşları (2001) Türkiye'de psikolojik problemlerinden dolayı yardım alma davranışlarını araştırmış ve katılımcıların \%12,3’ünün Müslüman şamanlara gittiğini, \%32,5’inin tıp doktorlarına başvurduğunu, \%32,5'in ise psikiyatristlere başvurduğunu tespit etmişlerdir. Bir başka araştırmada Yaşan ve Gürgen (2004) araştırmaya katılan psikiyatri hastalarının \%57'sinin, rehabilitasyon hastalarının ise \%15'inin Müslüman şamanlara başvurduğunu belirtmiştir.

Her ne kadar Müslüman şamanlara sıklıkla başvurulsa da, bu kişilerin niyetleri ve gerçekten faydalı olup olamadıkları konusunda tartışmalar vardır. Müslüman şamanların tartışmalı imajları birçok çalışmaya konu olmuştur. Örneğin Stirling (1965) Müslüman şamanlarla ilgili halk arasındaki algıyı “. .. çok saygı görmezler fakat bilgili, faydalı ve biraz da tehlikeli kişiler olarak algılanırlar" (s. 230) şeklinde özetlemiştir. Özdemir ve Frank de (2000) Müslüman şamanların dolandırıcı olarak algılanmalarına rağmen modern tıbbın ve psikolojinin imkânları tükendiğinde bu kişilere çokça başvurulduğunu belirtmiştir. Son olarak Dole (2006), Müslüman şamanların "itici çekiciliğinden" (s. 31) bahsetmiş ve onlarla ilgili medyada yer bulan skandallardan örnekler vermiştir.

Resmi İslami kaynaklar ve İslam âlimleri de halkı Müslüman şamanlara karşı uyarmaktadır (Diyanet İşleri Başkanlığı, b.t.). Bu kaynaklar ve âlimler, belli problemler için belli ayetleri okumanın faydalı olacağından bahsetmektedir. Örneğin, depresyon gibi ruhsal problemlere çare olarak Hazreti Muhammed'in üzüntüyle başa çıkmak için tavsiye ettiği Kur'an-I Kerim ayetlerini okumanın faydalarından bahsedilmekte, kişilere kaderlerini sabır ve dualarla karşılamaları salık verilmektedirler (Uzun, b.t.). Bu kaynaklar ayrıca Kur'an-I Kerim’i para karşıllğ̆ okuyan kişilere karşı uyarılarda bulunmakta (Diyanet İşleri Başkanlığı, b.t.), Kur'an-I Kerim’i kişinin kendisinin okumasının daha makbul olacağını, eğer bu mümkün değilse resmi görevlilere başvurmalarının daha iyi olacağını belirtmektedir (F. Aktaş, kişisel görüşme, Mayıs 28, 2009).

Özetle, hem türbe hem de hoca ziyaretlerinde İslam öncesi geleneklerle İslami gelenekler iç içe geçmiş durumdadır. Türbelerde bulunan levhalardaki bilgiler ve İslam âlimlerinin uyarılarına rağmen kişiler bu uygulamaları sürdürmektedir. Bunda, İslam öncesi inançların etkisinin yanı sıra bu uygulamaların sağaltıcı ve rahatlatıcı etkisinin de varlığı yadsınamaz. Psikologlar ve psikolojik danışmanlar bu sağaltıcı etkiyi inceleyerek kendi uygulamalarında kullanabilir, bu etkiden faydalanmaları için danışanları yönlendirebilirler.

\section{Yerel Sağaltım Yöntemleri Bağlamında İstanbul'dan Üç Türbe Örneği}

Telli Baba Türbesi. Telli Baba Türbesi İstanbul'un Sarıyer ilçesinde boğaza nazır bir tepenin üzerinde bulunmaktadır. Giriş kapısı tepenin üzerinde, binanın geri kalanı ise neredeyse yerin altında kalacak şekilde tepeden aşağ 1 doğru inşa edilmiştir. Türbe yapısının içinde bir tabutun ve mezar taşının bulunduğu bir oda, ayrıca namaz kılmak için bir kaç oda daha bulunmaktadır. Tabutun üzerine yeşil bir örtü örtülmüş, örtünün üzerinde gelin telleri ve ayakucunda ise makaslar bulunmaktadır. Odanın duvarlarında seccadeler ve ziyaretçiler tarafından bağışlanmış dini temalı, Kâbe fotoğrafı gibi süsler bulunurken, yerler halı kaplıdır ve içeri girerken ziyaretçilerden ayakkabılarını çıkarmaları istenmektedir.

Türbe görevlisiyle yapılan görüşmeden türbe ile ilgili daha detaylı bilgi edinilmiştir. Telli Baba Türbesi, Rumeli Kavağı Telli Baba Güzelleştirme ve Çevre Koruma Derneği'nebağlıdır. Türbe görevlisi, Telli Baba adlı şahsın asıl isminin Abdullah olduğunu, "Baba" adını sonradan 
aldığını ve Bizans döneminde Müslümanlığın yayılmasında görev aldığını belirtmiştir. Görevlinin belirttiğine göre, Telli Baba Müslüman yaptığı kızları gelin edermiş. Gelin olmak için kaçıp gelen kızların bazıları yolda vurulur, bazıları da boğazı geçerek gelirken boğulurmuş.

Günümüzde ziyaretçilerin çoğu Telli Baba Türbesi’ne evlenme dileğiyle gelmektedir. Yine türbe görevlisinin belirttiğine göre, ziyaretçilerden mum yakanlar, taş dizenler, bez bağlayanlar, tabutun örtüsünden parça kesmek isteyenler olmaktadır. Görevli bu tip davranışlara izin vermediğini, dileklerin Telli Baba'nın yüzü suyu hürmetine Allah’tan dilenmesi gerektiğini belirtmiştir. Görevli ayrıca, ziyaretçilerin tabutun üzerindeki tellerden keserek aldığını ve dilekleri geçekleşene kadar bu telleri yanlarında taşıdığını belirtmiş, diğer davranışları engelleyebilseler de tel kesme âdetini engelleyemediklerini, bu yüzden de tabutun üzerindeki tellerin kaldırılmadığını ifade etmiştir.

Yuşa Türbesi. Yuşa Türbesi Beykoz tepelerinde inşa edilmiş, İstanbul Müftülüğü’ne bağl1 bir külliyeden oluşmaktadır. Külliye bünyesinde açık alanda bulunan bir mezar, bir cami, kadınlar için bir mescit, adaklık, Beykoz Müftülüğü’ne bağlı bir kitap satış mağazası, dinlenme yeri, abdesthane ve görevlilerin lojmanları bulunurken, külliyesinin dışında çeşitli dükkân ve lokantalar yer almaktadır. Yuşa Türbesi, cami ve etrafını çeviren duvarlarıyla, Mehmed Said Paşa tarafindan 1755 'de inşa edilmiştir. Yuşa, ya da diğer adıyla Yesu'nun, Musa'dan sonra İsrailoğulları'na gönderilmiş bir peygamber ve Musa'nın yeğeni olduğu belirtilmektedir (Serin, 2005). Yuşa'nın nerede öldüğü ve gömüldüğü konusunda çelişkili hikâyeler vardır. Rivayetlerden birine göre, Yuşa üç bin yıl önce bir savaş sırasında Beykoz tepesinde ölmüştür. Yuşa türbesine müftülük tarafından asılan bilgilendirici bir levhaya göre ise, Yesu ismi Fenikeliler arasında "kurtarıcı" anlamına gelen bir kelimeden türemiş ve Karadeniz'den gözüken en yüksek tepe olduğu için bu tepeye Yesu ismi verilmiştir.

Yuşa türbesi ve cami imamı ile yapılan görüşmede, Yuşa'nın gerçek mezarının Filistin'de olma ihtimalinin daha güçlü olduğu ancak temsili mezar ya da makamlarının Beykoz, Mısır ve Ürdün'de de bulunduğu bilgisi edinilmiştir. Ayrıca, türbenin bulunduğu tepenin dev dağı olduğuna ve devlerin burada yattığına dair bir inanç olduğundan bahseden imam, türbenin bulunduğu alanın eski dinlerde de ziyaretgâh olduğunu belirtmiştir. Yuşa'nın mezarının 17 metre olduğuna dikkat çeken imam, Yuşa Aleyhisselam'ın büyüklügünden dolayı Marmara Denizi'nden bir ayağı Sarıyer'de bir ayağı Beykoz'da abdest aldığına dair bir inanç olduğunu, fakat bu gibi inançların İslam bilimi ya da tarihi bilgilere dayanmadığını, yine de bu büyük mezarın ziyaretçilerde hayret ve saygı uyandırdığını eklemiştir.

Yuşa Türbesine ziyaretçilerin \%80-90’1 psikolojik ya da maddi nedenlerle gelmektedir. Ziyaretçilerin yazıp türbeye bıraktıkları dileklere göre, türbeye kızının evlenmesini isteyen, kendisi evlenmek isteyen, bir hastalık için çare dileyen, çocuğunun üniversite sınavını kazanmasını dileyen, bir araba, bir arsa ya da bir ev beklentisi olan, eşiyle ya da ailesiyle problemler yaşayan ve bunlara çare arayan insanlar gelmektedir. Türbe imamı, İslam'da Allah'a ulaşmak için vesileler aranabildiğini, dua ederken özellikle hazreti peygamberimizin yaptığı güzel işlerin duaların kabulüne vesile kılınabileceğini belirtmiş; benzer şekilde, "Yarabbi, Yuşa Aleyhisselam hürmetine kabul buyurun" diyerek dua edilebileceğini eklemiştir. Bu tavsiyeleri ziyaretçilerle de paylaştıklarını belirten İmam, istekte bulunan ziyaretçilere belirtilen probleme uygun ayetlerin Türkçe anlamlarını okuduklarını ya da ziyaretçiye bu duayı kendisinin okuması için öğrettiklerini ve ziyaretçilerin bu sayede rahatladıklarını belirtmiştir. Son olarak, Yuşa Türbesi imamı bazı ziyaretçilerin cin ya da şeytan çarpması şikâyetiyle geldiğini özellikle konuşma yetisini kaybetmiş ya da sürekli kâbus gören çocukların getirildiğini, ancak cin çarpması gibi konuların kendi ihtisas alanı olmadığını ve bu yüzden bu kişileri tıp doktorlarına ya da bu konularda uzmanlaşmış hocalara yönlendirdiğini ifade etmiştir. 
Eyüp Sultan Türbesi. İstanbul Müftülügü̈ne bağlı bir diğer türbe de Eyüp Sultan Türbesi'dir. Bu türbe İstanbul'un Eyüp ilçesinde bulunmaktadır. Ebu Eyyub el-Ensari'nin Hazreti Muhammed'in bir yakını olduğu, 699 yılında İstanbul kuşatması sırsında öldüğü ve İstanbul'un o zamanki sınırlarının dışına gömüldüğ̈̈ belirtilmektedir (Serin, 2005). İstanbul'u fethinden sonra Fatih Sultan Mehmet Ebu Eyyub el-Ensari'nin gömüldüğü yerin bulunmasını istemiş ve fetihten kısa bir süre sonra mezarın bulunduğu yere türbe ve cami inşa edilmesini emretmiştir. Türbenin etrafında bir avlu, bir cami, bir abdesthane, Eyüp Müftülügü Din Hizmetleri ile Danışma ve Eyüp Müftülüğü Aile İrşat ve Rehberlik Büroları bulunmaktadır.

Eyüp Sultan Türbesinde de bulunan Aile Rehberlik Büroları Türkiye'nin birçok şehrinde 2003 ve 2010 yılları arasında kurulmuştur. Kuruluş amaçları ailelere dini bilgiler vermek, aile bütünlüğünü korumak ve ailevi problemlerin çözümünde dini yardım sağlamaktır (Din Hizmetleri Dairesi Başkanlığı, b.t.). Eyüp Müftülüğü’nden bir şef ve müftü yardımcısı ile görüşmeler yapılmış, özellikle Aile Rehberlik Bürosunun fonksiyonları hakkında bilgi alınmıştır. Bu bilgilere göre bu bürolara gelen ziyaretçilerden birçoğu dini nikâh talebiyle, sünnet olan çocuklar için dua okunması ricasıyla, alkol problemi ya da aile içi şiddet gibi ailevi problemlerle veya psikolojik problemlerle başvuru yapmışlardır. Bu gibi talepler karşısında Aile Rehberlik Bürosunda çalışan imam ve kuran kursu hocaları gerektiğinde danışanı devlet hastanelerine, psikologlara veya maddi yardım yapan vakıflara yönlendirmekte, okunabilecek ayetleri göstermekte, kişinin kendisinin hissederek okumasının daha hayırlı olacağını belirtmekte, para karşılığı başkasına okutmaktansa kendilerinin okumasını tembihlemektedirler. Ziyaretçiler, kadın veya erkek görevlilerle görüşmeyi tercih edebilmektedirler. Ziyaretçilerin başvuru nedenlerinin ve aldıkları hizmetlerin kaydı tutulmakta, bu kayıtlar il merkezlerine gönderilmekte ve daha iyi hizmet verme amaçlı kullanılabilmektedir.

Eyüp Müftülüğü Şefi ayrıca türbe inancının bir Türk İslam sentezi olduğunu, Türk inancına göre mezarların ve mezar taşlarının bulunduğunu, bunun ataları yâd etme inancına bağlı olduğunu, Arabistan'daki İslam uygulamalarında ise kalıcı mezar ve mezar taşlarının bulunmadığını belirtmiştir. Müftülük şefine göre, Türklerin İslam'ı kabulü sırasında bazı gelenekler İslam'a uygun ve hayırlı ise İslam bunları reddetmemiş, Türk İslam sentezine bir bakıma izin vermiş ve bu sentezden türbeler ortaya çıkmıştır. Şef ayrıca, türbe geleneğinin Arabistan'da bulunmadığına dikkat çekmiştir.

\section{Sonuç ve Tartışma}

Türkiye'de birçok kişi psikolojik problemlerine çare aramak amacıyla türbeleri ve hocaları ziyaret etmektedir. Bu ziyaretler, İslami ve bilimsel kaynaklarda eleştirilip İslam'la bağdaşmayan ve riskli yanlarının altı çizilse de, psikolojik problemi olan birçok kişi doktorlara veya psikologlara başvurmanın yanı sıra türbeleri ve hocaları da ziyaret etmeye devam etmektedir. Alanda çalışan psikologların ve danışmanların da gözlemleyebileceği gibi, birçok kişi psikolojik problemlere çare aramak için türbeleri ve hoca ziyaretlerini tercih edebilmektedir. Bazı psikologlar bu gibi taleplere ilişkin olarak, danışanın ihtiyaçları, beklentileri ve bunlara bağlı olarak problem odaklı aktif çözüm arama motivasyonunu değerlendirmek yerine bu taleplerin karşılandığı uygulamaları (türbe, hoca ziyaretleri gibi) kınamakta ve olumsuz tavırlarını da danışanlarına belli etmektedir. Ne var ki, danışanlar bu olumsuz tavırları sezdiklerinde bu uygulamalardan vazgeçmek yerine psikologdan saklamayı tercih edebilmektedirler, bu tutum da sürmekte olan terapötik ilişkiye zarar verebilmektedir.

Yerel sağaltım yöntemlerini kınamak ve olumsuz karşılamak yerine bir diğer alternatif ise, bu uygulamaların varlığını kabul ederek yararlarını ve zararlarını danışanın kültürü ve inançları bağlamında incelemek ve yeri geldiğinde kabul edebilmektir. Türbe ve hoca ziyaretlerinin, Batılı 
terapi yöntemlerinin içerdiği ortak faktörlerden bazılarını içermesi nedeniyle terapiyle benzeşen yanları olduğu söylenebilir. Makalenin başında da bahsedildiği gibi, örneğin umut besleme ve başvurulan yöntemin yararlı olacağına inanma (Pomerantz, 2013), hem Batılı terapilerde hem de yerel sağaltım yöntemlerinde önemli rol oynayan bir ortak faktördür. Yine, hem hoca ziyareti gibi yerel yöntemler hem de Batılı terapi yöntemleri, hizmet verenle hizmet alanın aralarında kurulan ilişkiye ve güvene dayanır. Bu güven ilişkisinin temel taşlarından biri de iki tarafın birbirini anlayabilmesidir. Kültürel yönden benzeşen ve dünya görüşleri ortak olan kişiler, doğal olarak, bu ittifakı daha kolay kuracaklardır. Dini inançlarına bağlı, muhafazakâr kültürden gelen danışanlar, kültürel açıdan kendilerine benzeyen, ya da en azından kendilerini anlayabilecek terapistlerle ya da yerel sağaltıcılarla daha kolay ilişki kurabilirler. Ne yazık ki terapi yöntemlerinin çoğu dini meseleleri göz ardı etmekte, terapistlerin çoğu ruhani (spiritual) meseleleri terapide ele almamaktadır. Bu durumda danışanlar, dini meseleleri de içeren psikolojik ihtiyaçlarını karşılamak için, kendilerini bu açıdan anlayabileceğini düşündükleri sağaltıcılara yönlenmektedirler.

Burada kastedilen terapistin inanmadığı yöntemleri uygulaması veya şüpheyle karşıladığı yöntemleri uygulayan kişilere danışan yönlendirmesi değildir. Kastedilen, terapistin kendisininkinden farklı yöntemlerin varlığına açık olması ve danışanın kültürünü ve inançlarını yadsımadan, bu kültüre uygun uygulamaları incelemesi, öğrenmesi, güvenilir kaynaklar bulduğunda, rahat ettiği ölçüde, bunları kendi uygulamalarına katması ve yine güvendiği ölçüde bu kaynaklara danışan yönlendirmesidir. Daha önce bahsi geçen bazı psikoloji kaynaklarında da (Atkinson ve ark., 1993; Gerstein ve ark., 2009), bu gibi yerel sağaltım yöntemlerinin kişilere faydalı olabileceği, psikologların bunları yok saymak yerine bu konularda bilgilenmeleri gerektiği belirtilmektedir. Bir psikoloğun inançları ne olursa olsun, danışanının inançlarına saygı göstermesi ve danışanın ruh sağlığı için faydalı olacaksa -danışanın da talebi üzerine- yerel sağaltım yöntemlerine yönlendirebilmesi gerekir. Bunun için de en azından bu uygulamalar konusunda bilgi sahibi olması, hatta gerektiğinde güvenilir kişileri ve kaynakları tavsiye edebilmesi tercih edilir. 


\section{Kaynaklar}

Atkinson, D. R., Thompson, C. E., \& Grant, S. K. (1993). A three-dimensional model for counseling racial/ethnic minorities. The Counseling Psychologist, 21, 257-277.

Bellér-Hann, I., \& Hann, C. (2001). Turkish Region: State, Market and Social Identities on The East Black Sea Coast. Sante Fe, NM: School of Ameircan Research Press.

Bolak-Boratav, H. (2004). Psychology at the Cross-Roads: The view from Turkey. In M. J.

Stevens and D. Wedding (Eds), Handbook of International Psychology (Vol. 19, pp. 311-330).

NewYork: Bruner-Routledge.

Canel-Çınarbaş, D., Çiftçi, A., \& Bulgan, G. (2013). Visiting Shrines: A Turkish religious practice and its mental health implications. International Journal for the Advancement of Counselling, 35,

16-32.

Canel-Çınarbaş, D., Korkut-Owen, F., \& Çiftçi, A. (2009). Counseling in Turkey: A blend of western science and eastern tradition. In L. H. Gerstein, P. P. Heppner, S. Ægisdóttir, S. A. Leung, \& K. L. Norsworthy (Eds.), International handbook of cross-cultural counseling: Cultural assumptions and practices worldwide (pp. 475-485). Thousand Oaks, CA: Sage.

Coker, E. M. (2009). Claiming the public soul: Reprsentations of Qur'anic healing and psychiatry in the Egyptian print media. Transcultural Psychiatry, 46, 472-794.

Çarkoğlu, A., \& Toprak, B. (2000). Turkiye'de din, toplum ve siyaset. Istanbul: TESEV Yayınları. Çıılak, N. (2002). Anadolu'da Ölüm Sonrası Mezarlıklar Çevresinde Oluşan İnanç ve Pratikler.

Türk Kültürü, 40, 605-614.

Demir, A. F., \& Çomak, N. A. (2009). Şaman ve Türk Dünyası. Istanbul: Bağlam.

Din Hizmetleri Dairesi Başkanlığı (b.t.). Aile İrşat ve Rehberlik. 15 Ocak, 2010,

http://www.diyanet.gov.tr/turkish/dinhizmetleriweb/giris.htm)

Diyanet İşleri Başkanlığı (b.t.). Dini Soruları Cevapandırma Komisyonu: Hastalık ve Tedavi. 12

Ocak, 2010,

http://sorusor.diyanet.gov.tr/fmi/xsl/fetva/y_dokumcevap.xsl?-db=FetvaVT\&-lay=wfkweb\&-recid $=947 \&-$ find $=$

Dole, C. (2006). Mass media and the repulsive allure of religiuos healing: The cinci hoca in Turkish modernity. International Journal of Middle East Studies, 38, 31-54.

El-Kadi, A. (1993). Health and healing in the Qur'an. In S. Athar (Ed.), Islamic perspectives in medicine. A survey of Islamic medicine: Achivements and conteporary issues (pp. 117-118). Indianapolis: American Trust.

Engin-Demir, C. (2003). Secularism and education in Turkey. In E. P. Quntero \& M. K. Rummel (Eds.), Becoming a teacher in the new society: Bringing communities and classrooms together (pp. 256-278). New York: Peter Lang.

Gerstein, L. H., Heppner, P. P., Ægisdottir, S., Leung, S. A., \& Norsworthy, K. L. (2009). International handbook of cross-cultural counseling: Cultural assumptions and practices worldwide. Thousand Oaks, CA: Sage.

İltar, G. (b.t.). Eski Türklerde Mezar Kültü ve Günümüze Yansımaları. 12 Ocak, 2010, http://www.hbektasveli.gazi.edu.tr/dergi_dosyalar/27-11-19.pdf

İnan, A. (1952). Müslüman Türklerde Şamanizm Kalıntıları. İlahiyat Fakültesi Dergisi, 4, 19-30. İnan, A. (1972). Tarihte ve Bugün Şamanizm: Materyaller ve Araştırmalar (2. bask1). Ankara: Türk Tarih Kurumu.

Kalafat, Y. (1998). Kuzey Azerbaycan, Doğu Anadolu, ve Kuzey Irak'da Eski Türk Dini İzleri. Ankara: Kültür Bakanlığı.

Kirmayer, L. J. (1999). Myth and ritual in psychotherapy. Transcultural Psychiatry, 36, 451-460. Köse, A. \& Ayten, A. (2010). Türbeler: Popüler Dindarlığın Durakları. İstanbul: Timaş. 
Moodley, R., \& West, W. (2005). Integrating traditional healing practices into counseling and psychotherapy. Thousand Oaks, CA: Sage.

Ocak, A. Y.(2000). Alevi ve Bektaşi İnançlarının İslam Öncesi Temelleri. İstanbul: İletişim Yayınevi.

Özdemir, A., \& Frank, K. (2000). Visible Islam in Modern Turkey. New York, NY: St. Martin's Press.

Pepitone, A. (1997). Nonmaterial beliefs: Theory and research in cultural social psychology. In C. McGarty \& S. A. Haslam (Eds.), The message of social psychology. Cambridge: Blackwell.

Pomerantz, A. M. (2013). Clinical Psychology: Science, Practice, and Culture (3rd Ed.). U.S.:

Sage.

Rassool, G. H. (2000). The crescent and Islam: Healing, nursing and the spiritual dimension. Some considerations towards an understanding of Islamic perspectives on caring. Journal of Advanced Nursing, 32, 1476-1484.

Serin, R. (2005). Maneviyat bahçesinin gülleri: İstanbul evliyaları, sahabe kabirleri. İstanbul: Pamuk Yayıncilık.

Stirling, P. (1965). Turkish Village. New York: John Wiley \& Sons.

Tanyu, H. (1967). Ankara ve çevresinde adak ve Adak Yerleri. Ankara: Ankara Üniversitesi, İlahiyat Fakültesi.

Uzun, T. (b.t.). Cin Büyü ve Nazardan Nasıl Korunmalıyız?: Cin Çarpması, Büyü ve Nazar Tedavisinde İslami Metodlar. Konya: Uysal Kitabevi.

Ünal, S., Özcan, Y., Emul, H. M., Çekem, A. B., Elbozan, H. B., \& Sezer, Ö. (2001). Hastalık açıklama modeli ve çare arama davranışı. Anadolu Psikiyatri Dergisi, 2, 222-229.

Yalom, I. D. \& Leszcz, M. (2005). The Theory and Practice of Group Psychotherapy (5th ed.). New York: Basic Books.

Yaşan, A. \& Gürgen, F. (2004). Psikiyatri ve fizik tedavi polikliniklerine başvuran hastaların geleneksel yardım arama davranışının karşılaştırılması. Dicle Tıp Dergisi, 31, 20-28. 


\section{Summary: \\ Islamic and Preislamic Beliefs and Psychology: Visiting Shrines and Hocas within the Context of Indigenous Healing Methods in Turkey}

Indigenous healing methods, such as visiting shrines, and their mental health benefits have gained importance. It has been argued that indigenous and traditional healing methods can enrich the knowledge base of counseling psychology, and aid in finding new solutions to old problems. Books regarding indigenous healing methods used in different cultures and religions, their mental health benefits, and the need to integrate such methods with Western modes of psychotherapy have been published. Moreover, it has been argued that the client's culture and level of acculturation should be assessed and the therapist should facilitate indigenous healing methods if the need arises during psychotherapy, and thus, the therapist should be knowledgeable about relevant indigenous healing methods. Therefore, the purpose of the present article is to discuss Turkish indigenous healing methods within the scope of visiting shrines and religious leaders, and to provide examples based on three shrines in Istanbul and interviews with officials at these shrines.

Keywords: Indigenous healing methods, visiting shrines, visiting religious leaders, counseling. 